\title{
Studi Perbandingan Pengelolaan Dan Penggunaan Sumberdaya Kelautan/Perikanan Selama Era Tahun 1988an (Studi Kasus Kota Ternate, Maluku Utara)
}

Comparison Study Of Management And Use Of Marine / Fisheries Resources During The Era In 1988 (Case Study Kota Ternate, North Maluku)

\author{
Andi Agus ${ }^{1}$ \\ ${ }^{1}$ Fakultas Perikanan dan Kelautan, Universitas Khairun, Ternate, Maluku Utara \\ E-mail : andi.agus3@gmail.com
}

\begin{abstract}
ABSTRAK
Penelitian ini dilakukan untuk mengetahui studi pengelolaan sumberdaya kelautan/perikanan tahun 1980an di Kota Ternate, Maluku Utara. Metode Penelitian yang dilakukan dalam penelitian ini adalah penelitian deskriptif qualitative dan Pengumpulan dan analisis data dilakukan secara deskriptif qualitative. Hasil penelitian menunjukkan bahwa dimensi alat tangkap yang digunakan masih kecil, belum ada mekanisasi dan masih menggunakan layar sebagai tenaga penggerak.Jaringan pemasaran hasil perikanan dalam bentuk segar dan olahan serta hasil laut di Kota Ternate sudah ada antar pulau atau daerah dan belum banyak regulasi yang mengaturnya serta gejolak harga belum terjadi.
\end{abstract}

Kata Kunci : Dimensi alat tangkap, Jaringan Pemasaran, Ikan segar, olahan dan Hasil-hasil laut.

\section{ABSTRACT}

This research was conducted to know about study of marine/fishery resource utilization Ternate Manucipality era 1988, North Molucca. It was carried out at December, 2015 in Ternate Manucipality. Method of research was included qualitatif descripted method and collected and also data analised within descriptic qualitatif. Research resulting showed that dimension of fishing gears were still small size, no mechanization and used screen for the sail. There were net working trading fresh and fickle fisheries and also marine resource resulted between Ternate and other area. Besides that it was not many regulations, so there were not price fluctuations.

Keywords: Fisheries resource, net working traiding, marine/fisheries fresh/fickle and marine resource resulted

\section{PENDAhuluan}

\subsection{Latar Belakang}

Indonesia adalah negara kepulauan dengan jumlah pulau kurang lebih 13.000 buah dimana beberapa diantaranya belum mempunyai nama dan berpenghuni serta memiliki garis panjang pantai terpanjang ketiga didunia. Dengan demikian negara kita mempunyai potensi sumberdaya perikanan yang sangat prospek untuk dikonservasi, dikelola dan dikembangkan pada saat sekarang dan yang akan datang. Perairan laut dan perairan darat, didalamnya termasuk 
perikanan tangkap dan budidaya yang masih berpeluang untuk terus dikonservasi, dikelola dan dikembangkan dioptimalkan.

Peran sektor kelautan/perikanan dari tahun ke tahun terhadap pendapatan devisa negara sangat nyata dan masih memungkinkan untuk ditingkatkan lagi, sepanjang potensi sumberdaya ini dioptimalkan pemanfaatannya dengan tetap menjaga kelestariannya dengan cara manajemen dan konservasi. Hal ini penting untuk dilakukan, mengingat di negara kita ini dan dalam era globalisasi, kelestarian sumberdaya perikanan menjadi fokus perhatian penting. Penangkapan yang berlebihan (over fishing), destruktive fishing, illegal fishing, unreported dan unregulatedmasih menjadi masalah yang serius dalam pengelolaan wilayah laut di Indonesia. Ini akan mengakibatkan kelestarian sumberdaya perikanan terancam ditandai dengan semakin berkurangnya hasil tangkapan nelayan pada beberapa daerah tertentu di Indonesia, sehingga nelayan-nelayan semakin jauh fishing groundnya dari fishing base dibandingkan beberapa era tahun sebelumnya. Untuk itu perlu dilakukan pemulihan kestabilan sumberdaya perikanan dengan melakukan konservasi dan managemen pengelolaan sumberdaya perikanan.

Sebelum era tahun 1988, alat tangkap yang digunakan nelayan tradisional masih menggunakan tenaga manual dan kapal masih digerakkan dengan layar. Tentunya hal ini berpengaruh terhadap dimensi alat tangkap, jarak dan waktu ke fishing ground dan lain-lain. Dengan demikian terdapat perbedaan hal-hal tersebut diatas setelah era tahun 1988. Selain itu pengelolaan dan penggunaan sumberdaya kelautan/perikanan sudah terjadi sejak dari dulu berupa perdagangan antar pulau atau daerah terutamahasil-hasil laut seperti kerang-kerangan, sirip hiu dan teripang.Nelayan di Ternate khususnya dan Maluku Utara pada umumnya menggunakan berbagai jenis dan type alat tangkap jaring lingkar (encircling net), jaring angkat (lifth net), jaring insang (gill net), dan alat tangkap pancing (fishing line) serta jenis alat tangkap lainnya (Ayodhyoa, A.U. 1979; Brandt, V, 1984; Masatsune, M, and Tomeyoshi Yamazaki, 1979; Murdiyanto, B., Mangunsukarto, Kusman., dan Hestirianto, T., 1985; Sadhori, N.S. 1985; Sudirman dan Mallawa, A. 2002; Sudirman., 2012).

Era tahun 1988an adalah titik kulminasi perubahan pengelolaan dan penggunaan sumberdaya kelautan dan perikanan dengan masih menggunakan layar sebagai tenaga penggerak dan dimulainya mekanisasi dengan penggunaan mesin sebagai tenaga penggerak kapal dan alat bantu penangkapan ikan. Pengecualian ini berlaku untuk perusahaan yang bergerak dibidang perikanan perikanan dan dibiayai orang asing atau join venture dengan perusahaan lokal sudah menggunakan mekanisasi unit alat tangkap dan banyak beroperasi di daerah lain di Maluku terutama bagian selatan, misalnya pada perikanan trawl. Paper ini akan membahas tentang pengelolaan dan penggunaan sumberdaya kelautan/perikanan nelayan sebelumera tahun 1988an pada Kota Ternate, Maluku Utara.

\subsection{Tujuan dan Kegunaan}

Tujuan dilakukannya penulisan paper untuk mengetahui tentang pengelolaan dan penggunaan sumberdaya kelautan/perikanan oleh nelayan era 1988an di Kota Ternate, Maluku Utara. Kegunaannya adalah sebagai bahan informasi dan menjadi bahan penelitiaan selanjutnya terutama bagi peneliti atau berbagai pihak yang terkait dengan sumberdaya kelautan/perikanan beserta jaringan pemasarannya. 


\section{Metode Penelitian}

\subsection{Waktu dan Tempat Penelitian}

Penelitian ini dilakukan selama bulan Desember 2005 dan bertempat di Kota Ternate, Maluku Utara.

Metode penelitian yang dipakai dalam penelitian ini adalah metode penelitian deskriptif kualitatif menurut Salam, 2011.Selanjutnya data dianalisis secara deskriptip kualitatif menurut Salam, 2011.

\section{Hasil Dan Pembahasan}

Pengelolaan dan Penggunaan Sumberdaya Kelautan/Perikanan oleh Nelayan Selama Era Tahun 1988an di Kota Ternate

\subsection{Perubahan Terhadap Manajemen dan Teknologi Penangkapan Hasil Kelautan/Perikanan}

Penggunaan alat tangkap di Kota Ternate sebelum era tahun 1988an masih menggunakan layar/dayung sebagai tenaga penggerak.Kapal-kapal yang digunakan untuk alat tangkap jarring (lokal, giob), purse seine dan berbagai jenis pancing mulai dari pancing hand line (lokal, pancing rangke) sampai pole and line (lokal, pancing cakalang) masih menggunakan layar/dayung dalam usaha melakukan penangkapan ikan.

Memasuki era tahun 1988an, beberapa kapal penangkap sudah mulai menggunakan mesin sebagai alat penggerak meskipun belum umum dipergunakan.Dengan penggunaan mesin sebagai alat penggerak meskipun belum umum digunakan berpengaruh terhadap dimensi kapal dan alat tangkap.

Penggunaan layar sebagai tenaga penggerak, jumlah Gross tonnage (GT) kapal untuk kapal pole and line masih berkisar sekitar 17 - $20 \mathrm{GT}$, sedangkan dengan tenaga mesin Gross tonnage kapal berkisar 30an GT.Selain itu penggunaan tenaga mesin jumlah pemancing lebih sekira 1720 orang per kapal, sedangkan pada kapal yang memakai layar menggunakan pemancing atau fishing master sekira 15 orang.

Kapal-kapal yang dibangun pada era tahun 1980-an terbuat dari kayu. Kayu-kayu kelas satu seperti kayu bayam dan bitti serta kayu kelas dua seperti kayu meranti banyak digunakan sebagai bahan pembuat kapal.Daerah-daerah pembuatan kapal pada era ini terdapat didaerah pesisir Ternate dan Tidore serta pulau-pulau disekitarnya dan pesisir pulau Halmahera beserta pulaupulaunya.

Dimensi alat tangkap diera tahun 1980an mulai dari berbagai jenis jarring terutama purse seine masih kecil, jumlah pemancing lebih sedikit seperti yang telah dijelaskan diatas untuk pole and line dengan penggunaan layar sebagai tenaga penggerak dibandingkan dengan menggunakan mesin.

Alat tangkap bagan di era ini sudah mulai dikenal didaerah Ternate dengan menggunakan lampu petromaks atau strongkin untuk mengumpulkan ikan.Nelayan Ternate banyak mengoperasikannya pada perairan Teluk Kao, Akelamo dan Bobaneigo serta Toniku di Halmahera. Toniku sampai sekarang menjadi desa dengan penduduk sebagian besar menggunakan bagan sebagai alat menangkap ikan dengan hasil tangkapan utama ikan teri (Stolephorus sp) atau (lokal, ikan ngafi). Menurut Sudirman dan Mallawa (2002) alat tangkap bagan termasuk didalamnya bagan perahu atau rambo untuk pertamakalinya diperkenalkan oleh nelayan Sulawesi Selatan di Indonesia. 
Pada era ini sudah dikenal alat tangkap purse seine (local, pajeko) oleh nelayan Ternate.Pengenalan alat ini diperoleh dari nelayan Manado, Sulawesi Utara.Penduduk pesisir Manado sebagian merupakan orang-orang Ternate yang sudah lama menetap secara turun temurun.

\subsection{Penentuan Daerah Penangkapan, Pengolahan dan Pemasaran Hasil Kelautan/Perikanan}

Pada era tahun 1988an penentuan daerah penangkapan sebagian masih menggunakan tandatanda alam seperti adanya burung dan ikan lumba-lumba sebagai tanda adanya gerombolan ikan atau banyak ikan pada suatu daerah penangkapan atau fishing ground.

Daerah penangkapan berbagai jenis alat tangkap terdapat disekitar perairan Ternate serta pulau Halmahera dan pulau-pulau disekitarnya seperti Bacan, Obi, Morotai, loloda dan lainlain.Nelayan pada era ini menggunakan layar/dayung untuk melakukan penangkapan ikan didaerah-daerah tersebut. Apabila hasil tangkapan banyak, biasanya nelayan akan mengolahnya menjadi ikan asap. Ikan yang banyak diolah untuk ini adalah ikan cakalang (lokal, ikan fufu) dengan menggunakan pancing pole and line, terkadang tertangkap dengan purse seine, sedangkan dengan menggunakan jaring (lokal, pukat) adalah ikan selar (Serraides sp) dan julung-julung (Hemirhamphus sp) yang disebut (lokal, ikan tore).

Musim penangkapan diperairan Ternate pada musim barat atau angin utara yaitu angin yang bertiup dari arah barat cenderung dari utara untuk Ternate dan Maluku Utara pada umumnya.Ombak tidak terlalu besar, sehingga memungkinkan untuk melakukan pengoperasian berbagai jenis alat tangkap.

Pada musim timur, yaitu angin yang bertiup dari timur cenderung dari selatan untuk Ternate dan Maluku Utara pada umumnya, ombak disekitar perairan Ternate besar sehingga kurang memungkinkan untuk pengoprasian berbagai jenis alat tangkap. Nelayan biasanya melakukan usaha penangkapan disekitar perairan Kepulauan bacan dan Pulau Obi. Dengan menggunakan layar perairan ini ditempuh selama 3 jam sedangkan kalau angin tidak kencang bisa ditempuh selama seminggu.

Ikan-ikan hasil tangkapan dalam bentuk segar dipasarkan didaerah pesisir pada fishing base daerah penangkapan. Tetapi apabila fishing groundnya jauh dari fishing base maka ikan-ikan segar tadi diolah menjadi ikan olahan seperti ikan kering, asap (lokal, ikan fufu) dan ikan asap kering (lokal, ikan tore).

Ikan-ikan dasar jenis ikan kakap, kerapu dan jenis lainnya serta ikan teri oleh nelayan Ternate dan daerah lainnya di Maluku Utara kebanyakan dikeringkan. Ikan cakalang (Katsuwous pelamis) yang dibuat menjadi ikan asap, prosesnya hampir sama dengan masyarakat lain di Indonesia dalam membuat ikan asap dan bisa tahan selama 2-3 hari. Ikan asap kering, proses pembuatannya hampir sama kalau membuat kelapa menjadi kopra dan bisa tahan dalam waktu yang cukup lama atau berbulan-bulan.

Pemasaran hasil-hasil laut diera tahun 1980an sudah dilakukan didaerah Ternate seperti berbagai jenis kerang-kerangan, sirip ikan hiu dan teripang.Terdapat pedagang hasil laut di Ternate yang membangun usahanya sejak tahun 1970an.Pada era ini belum terlalu banyak regulasi atau peraturan yang berhubungan dengan pengelolaan sumberdaya kelautan/perikanan dan pemasaran hasilnya, sehingga hasil-hasil laut dengan berbagai jenis seperti yang disebutkan diatas bisa dieksploitasi dan diperdagangkan antar daerah atau pulau secara bebas.Sirip ikan hiu adalah 
penganan yang dibuat menjadi bubur oleh orang tiongkok, sedangkan teripang adalah penganan khas orang tiongkok yang sangat disukai dan harganya sangat mahal.

Hasil-hasil laut nelayan pada era ini cenderung masih banyak dengan harga yang cukup stabil diperdagangkan antar daerah atau pulau yang kemudian dieksport ke luar negeri.Tidak ada gejolak harga yang merugikan baik pada tingkat nelayan, pedagang menengah dan besar.

\section{Kesimpulan}

Beberapa kesimpulan yang dapat ditarik dari pembahasan diatas adalah sebagai berikut :

1. Dimensi Alat Tangkap yang digunakan oleh nelayan tradisional masih berukuran kecil dan menggunakan layar untuk melayarkan kapal penangkap selama era tahun 1980-an.

2. Daerah Penangkapan (fishing ground) masih sangat terbatas karena pengoperasian alat tangkap masih manual dan menggunakan layar sehingga faktor angin menjadi sangat penting.

3. Jaringan pemasaran hasil perikanan dalam bentuk segar dan olahan serta hasil laut di Kota Ternate sudah dilakukan antar pulau dan daerah, masih kurang regulasi yang mengatur tentang hal tersebut, hasil tangkapan masih banyak dan tidak adanya gejolak harga yang merugikan nelayan, pedagang menengah dan besar.

\section{Ucapan Terima Kasih}

Penulis memberikan ucapan terima kasih kepada Prof. Katsuya Osozawa, Professor dalam bidang Maritime World Study pada Faculty of Agriculture, Ehime University, Japan atas petunjuk, nasehat, bimbingan dan motivasi yang diberikan sebelum dan selama pembuatan paper ini. Penulis juga mengucapkan terima kasih kepada pihak-pihak penentu kebijakan di Universitas Khairun, Ternate, Maluku Utara.Selain itu penulis mengucapkan terima kasih pada masyarakat pesisir Kota Ternate, Maluku Utara atas informasi yang diberikan sehubungan dengan pengelolaan dan penggunaan sumberdaya kelautan/perikanan mereka.

\section{Daftar Pustaka}

Ayodhyoa, A.U. 1979. Metode Penangkapan Ikan. Yayasan Dewi Sri.Bogor.

Brandt, A von. 1984.Fish Catching Methods of the World. Fishing News Books Ltd. Farnham Surrey England.

Masatsune, Nomura and Tomeyoshi Yamazaki. 1977. Fishing Techniques. Compilations of Transcript of Lectures Presented at the Training Department. SEAFDEC.Japan International Cooperations Agency.Tokyo. Japan.

Murdiyanto, B., Mangunsukarto, Kusman., dan Hestirianto, T., 1985. Modul AlatAlat Penangkapan Ikan. Departemen Pendidikan Dan Kebudayaan. Proyek

Sistem Pendidikan Jarak jauh Dengan Satelit (SISDIKSAT) BKS PTN INTIM_IPB_USAID/AED.

Salam, M. 2011. Metodologi penelitian sosial kualitatif: menggugat doktrin kuantitatif. Masagena Press. Makassar.

Sadhori, N.S. 1985. Teknik Penangkapan Ikan. Angkasa. Bandung.

Sudirman dan Mallawa, A. 2002. Teknik Penangkapan Ikan. CV. Rineke Cipta. Jakarta.

Sudirman., 2012., Alat dan Metode Penangkapan Ikan.CV. Rineke Cipta. Jakarta. 